\title{
Article \\ Excellent Properties of Ni-15 wt.\% W Alloy Electrodeposited from a Low-Temperature Pyrophosphate System
}

\author{
Changwei Su ${ }^{1,2,3, *,+}{ }^{\mathbb{D}}$, Zhaoyao Sa ${ }^{2,3,+}$, Yangyang Liu ${ }^{1}$, Linfu Zhao ${ }^{2,3}$, Fengjing $\mathrm{Wu}^{1}$ and Wei Bai ${ }^{2,3}$ \\ 1 College of Materials and Chemical Engineering, Hunan Institute of Engineering, Xiangtan 411104, China; \\ Liuyangyang@ynni.edu.cn (Y.L.); wfj2013@aliyun.com (F.W.) \\ 2 Key Laboratory of Green-Chemistry Materials in University of Yunnan Province, Yunnan Minzu University, \\ Kunming 650500, China; Sazhaoyao@ynni.edu.cn (Z.S.); Zhaolinfu@ynni.edu.cn (L.Z.); \\ weibai@ynni.edu.cn (W.B.) \\ 3 National and Local Joint Engineering Research Center for Green Preparation Technology of Biobased \\ Materials, Yunnan Minzu University, Kunming 650500, China \\ * Correspondence: abrastein@163.com; Tel./Fax: +86-871-65910014 \\ + The authors contributed equally to this work as first authors.
}

Citation: Su, C.; Sa, Z.; Liu, Y.; Zhao, L.; Wu, F.; Bai, W. Excellent Properties of Ni-15 wt.\% W Alloy

Electrodeposited from a Low-Temperature Pyrophosphate System. Coatings 2021, 11, 1262. https://doi.org/10.3390/ coatings 11101262

Academic Editor: Alina Pruna

Received: 13 September 2021

Accepted: 11 October 2021

Published: 18 October 2021

Publisher's Note: MDPI stays neutral with regard to jurisdictional claims in published maps and institutional affiliations.

Copyright: () 2021 by the authors. Licensee MDPI, Basel, Switzerland. This article is an open access article distributed under the terms and conditions of the Creative Commons Attribution (CC BY) license (https:// creativecommons.org/licenses/by/ $4.0 /)$.

\begin{abstract}
Electrodeposited Ni-W alloy coatings are considered to be one of the most suitable candidate coatings to replace carcinogenic hexavalent chromium coatings. In this work, Ni-W alloys are electrodeposited from pyrophosphate baths containing different concentrations of $\mathrm{Na}_{2} \mathrm{WO}_{4} 2 \mathrm{H}_{2} \mathrm{O}$ $\left(C_{W}\right)$ at $40{ }^{\circ} \mathrm{C}$. Both $C_{W}$ and the applied current density can affect the $\mathrm{W}$ content in the coatings. The effect of $C_{W}$ becomes weaker with the increased current density. The Ni-W alloys with $15 \pm 5$ wt. $\%$ $\mathrm{W}(\mathrm{Ni}-15 \mathrm{wt} . \% \mathrm{~W})$ are obtained from the bath containing $40 \mathrm{~g} \mathrm{~L}^{-1} \mathrm{C}_{\mathrm{W}}$ at a high current of $8 \mathrm{~A} \mathrm{dm}^{-2}$. The microhardness, corrosion resistance and hydrogen evolution reaction (HER) are measured with a microhardness tester and an electrochemical workstation. The modified properties are studied by heat treatment from 200 to $700{ }^{\circ} \mathrm{C}$. The highest microhardness of $895.62 \mathrm{HV}$ and the better HER property is presented after heat treatment at $400{ }^{\circ} \mathrm{C}$, while the best corrosion resistance in $3.5 \mathrm{wt} . \%$ $\mathrm{NaCl}$ solution appears at $600{ }^{\circ} \mathrm{C}$.
\end{abstract}

Keywords: anti-corrosion; coatings; Ni-W alloy; pyrophosphate; HER; electrodeposition

\section{Introduction}

With the development of science and technology, the corrosion resistance and other performance requirements of materials are continuously improved [1]. In order to improve the wear resistance and corrosion resistance of materials, materials such as nickel, cobalt, titanium and tungsten-based alloys and ceramics are usually used as coating materials $[2,3]$. Many studies have also reported that nickel-based coatings improve the wear and corrosion resistance of the substrate [4,5], by means of physical, chemical and electrochemical deposition. Electrodeposition is one of the most important technologies for preparing metal and alloy coatings [6]. In recent years, the research of $\mathrm{Ni}-\mathrm{W}$ and Ni-W-based coatings has received extensive attention [7-9]. The $\mathrm{Ni}-\mathrm{W}$ electroplating layer is considered to be one of the candidates to replace hard chromium plating due to its smooth surface, high hardness, excellent wear resistance, good corrosion resistance and low cost. It is widely used in the protective coating of glass membranes, hydraulic parts and valves [10].

Environmentally friendly hydrogen energy is an alternative to fossil energy [11]; therefore, electrolytic hydrogen production technology has attracted the extensive interest of researchers [12]. However, a high-energy consumption resulted from the high overvoltage of the hydrogen evolution reaction (HER) limits its practical and wide application [13]. Some materials with a low HER overvoltage and low price have become a research focus [14]. For example, transition metals such as Ni, W, Co and their alloys have attracted widespread attention in the past few years due to their richness, low cost, and high elec- 
trocatalytic performance [15]. In nickel-based alloys, Ni-W can be selected for a suitable hydrogen production process due to its high potential and strong corrosion resistance [16].

In this work, Ni-W alloy coatings were prepared by electrodeposition in a lowtemperature pyrophosphate bath and their corrosion resistance and HER properties were studied in detail. Heat treatment was carried out to improve their microhardness [17,18], corrosion resistance and HER properties. The organic chelating agents, such as citric acid, were usually added into baths to obtain $\mathrm{Ni}-\mathrm{W}$ alloys with good wear and corrosion resistance [19]. However, the organic chelating agents inevitably decompose during electroplating, and the electro-productions are difficult to remove completely, usually resulting in bad coatings which peel and have a low hardness. Pyrophosphate, a carbon-free chelating agent, is widely used in the electroplating field, while Ni-W coatings from the bath are rarely reported [20]. Therefore, the pyrophosphate chelating agent was selected in this work.

\section{Materials and Methods}

\subsection{Electrodeposition of Ni-W Alloys}

A pyrophosphate bath was used to prepare $\mathrm{Ni}-\mathrm{W}$ coating. Table 1 lists its components and process parameters. The bath was prepared with analytical reagents and deionized water. The additions used were from Hunan Nano-film New Material Technology Co., Ltd. (Changsha, China).

Table 1. Bath compositions and plating conditions for Ni-W alloy coatings from a pyrophosphate system.

\begin{tabular}{cc}
\hline Chemicals/Parameters & Values $(\mathrm{g} / \mathrm{L})$ \\
\hline $\mathrm{NiSO}_{4} \cdot 6 \mathrm{H}_{2} \mathrm{O}$ & 12 \\
$\mathrm{NaWO}_{4} \cdot 2 \mathrm{H}_{2} \mathrm{O}$ & $20,30,40,50,60$ \\
$\mathrm{Na}_{4} \mathrm{P}_{2} \mathrm{O}_{7} \cdot 10 \mathrm{H}_{2} \mathrm{O}$ & 40 \\
$\mathrm{H}_{3} \mathrm{PO}_{4}(85 \%)$ & 10 \\
$\mathrm{NH}_{3} \cdot \mathrm{H}_{2} \mathrm{O}(25-28 \%)$ & 20 \\
Additions & 20 \\
\hline Bath temperature & $40{ }^{\circ} \mathrm{C}$ \\
Current density & $4-10 \mathrm{~A} / \mathrm{dm}^{2}$ \\
pH & $8.5-9.0$ \\
\hline
\end{tabular}

Ni-W alloy coatings were deposited on Q235 carbon steel disks with a diameter of $10 \mathrm{~mm}$ and a thickness of $2 \mathrm{~mm}$ in a $500 \mathrm{~mL}$ plating bath under a constant current density of 4, 6, 8 and $10 \mathrm{~A} \mathrm{dm}^{-2}$ by DC power supply (APS3005DM, ATTEN/Antaixin, Hangzhou Hamat Electronics Co., Ltd., Hangzhou, China) keeping the bath temperature at $40^{\circ} \mathrm{C}$. Before electroplating, the disks were mechanically polished with $\mathrm{SiC}$ waterproof sandpaper (CW-800, Shanghai Xinshangsha Abrasives Co., Ltd., Shanghai, China) and electrochemically degreased in $40 \mathrm{~g} \mathrm{~L}^{-1} \mathrm{NaOH}$ for $10 \mathrm{~min}$ and rinsed with deionized water, and then washed and activated in $10 \% \mathrm{HCl}$ for $10 \mathrm{sec}$. The electrodeposition time was $135 \mathrm{~min}$ to ensure a coating thickness over $100 \mu \mathrm{m}$, which could meet the microhardness measure and heat treatment. After electrodeposition, $\mathrm{Ni}-\mathrm{W}$ alloy coatings were immediately rinsed with deionized water, dried by a blow drier and placed into a self-sealing bag.

The carbon steel disks coated with Ni-W alloys were annealed at 200, 300, 400, 500, 600 , and $700{ }^{\circ} \mathrm{C}$ for $2 \mathrm{~h}$ in a muffle furnace.

\subsection{Characterization}

Chemical composition of all as-prepared samples was analyzed using energy-dispersive X-ray spectroscopy (EDX, EDX-8000, Shimadzu, Kyoto, Japan). Microscopic morphology was analyzed by scanning electron microscope (SEM, Nova 450, FEI, Hillsboro, OR, USA). Crystal structure was characterized by X-ray diffraction (XRD, D8 Advance, Bruker, Billerica, MA, USA) using $\mathrm{Cu} \mathrm{K} \alpha$ radiation with $\lambda=0.15406 \mathrm{~nm}$ between a $2 \theta$ range from 30 to 
$90^{\circ}$, at a tube voltage of $40 \mathrm{kV}$ and with a tube current of $40 \mathrm{~mA}$. Their average grain size was calculated according to the Debye-Scherrer formula, $d=0.89 \lambda /(\beta \cos \theta)$ [21]. The grain size here was estimated based on the (1 111 ) diffraction peak. TG-DSC (thermogravimetric analysis-differential scanning calorimetry) tests were performed using a thermal analyzer (STA449F3, Netzsch, Selb, GER) in air from room temperature to $800^{\circ} \mathrm{C}$. The Ni-W alloy coating quality was $10 \mathrm{mg}$, which was stripped from a 304 stainless steel disk that had a low adhesion and could easily fall off.

Annealed samples at over $400{ }^{\circ} \mathrm{C}$ were polished with $\mathrm{W}(14,7$ and 3.5) metallographic sandpaper in sequence, while other samples were not polished because of the bright surface. Then, Vickers microhardness of the coating was measured using the HV-1000A microhardness tester (Laizhou Huayin Testing Instrument Co., Ltd., Laizhou, China). Take an indentation load of $100 \mathrm{gf}$ and a residence time of $10 \mathrm{~s}$, the average value of the five different positions was measured as the coating hardness.

\subsection{Electrochemical Measurements}

After a copper wire was welded on the Q235 carbon steel disks coated with Ni-W alloys, they were sealed by epoxy resin and were successively polished with $\mathrm{SiC}$ (CW-600, 800 and 1000) waterproof abrasive papers to expose a Ni-W alloy surface with $0.785 \mathrm{~cm}^{2}$. The saturated calomel electrode (SCE) and platinum plate were, respectively, used as reference electrode (RE) and auxiliary electrode (CE) on the electrochemical workstation to measure the electrochemical performance of the prepared electrode (working electrode, $\mathrm{WE}$ )., In a $3.5 \mathrm{wt} . \% \mathrm{NaCl}$ solution, the Tafel curves were carried out at a scan speed of $1 \mathrm{mV} \mathrm{s}^{-1}$ between $\pm 250 \mathrm{mV}$ of open circuit potential (OPE) and electrochemical impedance spectroscopy (EIS) was performed with an applied AC signal amplitude of $5 \mathrm{mV}$ and a scanning frequency of $0.01 \mathrm{~Hz}$ to $100 \mathrm{kHz}$. In a $6 \mathrm{wt} . \% \mathrm{NaOH}$ solution, the behavior of HER was estimated using LSV electrochemical technology at a scan rate of $5 \mathrm{mV} \mathrm{s}^{-1}$. The $\mathrm{E}$ (vs. RHE, Reversible Hydrogen Electrode) potential was calculated according to the following formula [22].

$$
\mathrm{E}(\text { vs. RHE })=\mathrm{E}(\mathrm{vs} . \mathrm{SCE})+\mathrm{E}_{\mathrm{SCE}}(0.241 \mathrm{~V})+0.0592^{*} \mathrm{pH}
$$

\section{Results and Discussion}

\subsection{Electrodeposition of $\mathrm{Ni}-\mathrm{W}$ Alloys}

Figure 1a shows the EDX spectra of $\mathrm{Ni}-\mathrm{W}$ alloy coatings prepared at current densities of 4, 6, 8 and $10 \mathrm{~A} \mathrm{dm}^{-2}$ from the pyrophosphate bath containing $40 \mathrm{~g} \mathrm{~L}^{-1} \mathrm{Na}_{2} \mathrm{WO}_{4} 2 \mathrm{H}_{2} \mathrm{O}$ at $40{ }^{\circ} \mathrm{C}$. From Figure 1a, the characteristic peaks of the $\mathrm{Ni}$ and $\mathrm{W}$ elements all appear at $0.85 \mathrm{KeV}$ and $7.47 \mathrm{KeV}$, and $1.78 \mathrm{KeV}$, respectively, implying that the co-deposition of $\mathrm{Ni}$ and $\mathrm{W}$ has occurred.
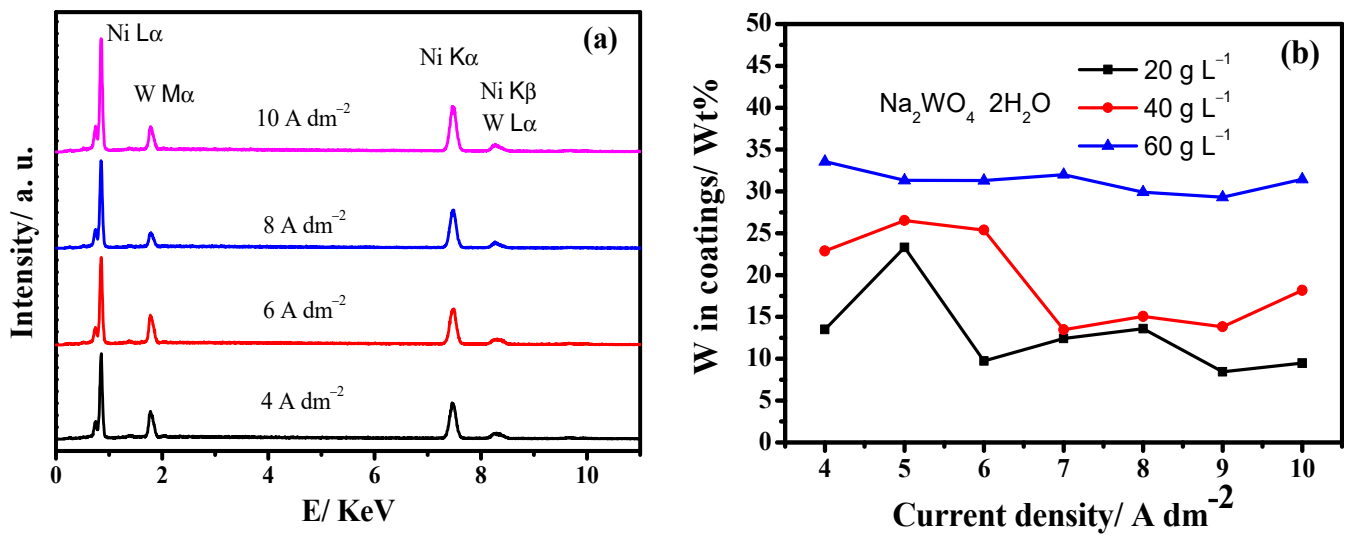

Figure 1. (a) EDX spectra of N-W alloy coatings prepared at different current densities from the pyrophosphate bath containing $40 \mathrm{~g} \mathrm{~L}^{-1} \mathrm{Na}_{2} \mathrm{WO}_{4} \cdot 2 \mathrm{H}_{2} \mathrm{O}$ at $40{ }^{\circ} \mathrm{C}$. (b) The relationship between current density and $\mathrm{W}$ content in the coatings electrodeposited from the baths containing different concentrations of $\mathrm{Na}_{2} \mathrm{WO}_{4} \cdot 2 \mathrm{H}_{2} \mathrm{O}$. 
As Figure $1 \mathrm{~b}$ shows, in general, in $40 \mathrm{~g} \mathrm{~L}^{-1} \mathrm{Na}_{2} \mathrm{WO}_{4} 2 \mathrm{H}_{2} \mathrm{O}$ concentration, the $\mathrm{W}$ content in Ni-W alloy coatings first increase and then decrease with the increase in current density. The Ni-W alloy coatings with about $15 \mathrm{wt} . \% \mathrm{~W}$ can be obtained at a wide range of current density. When the concentration of $\mathrm{Na}_{2} \mathrm{WO}_{4} 2 \mathrm{H}_{2} \mathrm{O}$ to $20 \mathrm{~g} \mathrm{~L}^{-1}$ decreases, the same changing trend is also presented in Figure $1 \mathrm{~b}$. This is the competition of the reduction of adsorptive species $\mathrm{NiOH}_{\text {ads }}$ and intermediate $\left[(\mathrm{Ni})_{\mathrm{p}}\left(\mathrm{WO}_{4}\right)_{\mathrm{q}}\left(\mathrm{P}_{2} \mathrm{O}_{7}\right)_{\mathrm{m}}\right]^{2(\mathrm{p}-\mathrm{q}-2 \mathrm{~m})}$, which affect the $\mathrm{W}$ content, along with current density. The $\mathrm{W}$ content resulting from the intermediate reduction increases and decreases because of its more positive potential and low diffusion rate, respectively. In the high $\mathrm{Ni}$ bath, this change trend was also observed by Suvorov et al. [20]. They considered that the electrochemical reduction of $\mathrm{Ni}$ ions was carried out through three subsequent reactions, while the deposition of $\mathrm{W}$ could be induced by means of the Ni adsorptive species $[20,23]$. That is, the $\mathrm{NiOH}_{\text {ads }}$ was further reduced by two routes of (3) and (6), and the competition between them led to the change in tungsten content:

$$
\begin{gathered}
{\left[\mathrm{Ni}\left(\mathrm{P}_{2} \mathrm{O}_{7}\right)_{2}\right]^{6-}+\mathrm{OH}^{-} \rightarrow \mathrm{P}_{2} \mathrm{O}_{7}{ }^{4-}+\left[\mathrm{Ni}(\mathrm{OH})\left(\mathrm{P}_{2} \mathrm{O}_{7}\right)\right]^{3-} \text { ads }} \\
{\left[\mathrm{Ni}(\mathrm{OH})\left(\mathrm{P}_{2} \mathrm{O}_{7}\right)\right]^{3-} \text { ads }+\mathrm{e}^{-} \rightarrow \mathrm{NiOH}_{\mathrm{ads}}+\mathrm{P}_{2} \mathrm{O}_{7}{ }^{4-}} \\
\mathrm{NiOH}_{\text {ads }}+\mathrm{e}^{-} \rightarrow \mathrm{Ni}^{0}+\mathrm{OH}^{-} \\
\mathrm{NiOH}_{\mathrm{ads}}+\mathrm{WO}_{4}{ }^{2-} \rightarrow\left[\mathrm{WO}_{4}(\mathrm{NiOH})\right]^{2-} \text { ads } \\
{\left[\mathrm{WO}_{4}(\mathrm{NiOH})\right]^{2-}{ }_{\text {ads }}+\mathrm{e}^{-} \rightarrow\left[\mathrm{WO}_{4}(\mathrm{Ni})\right]^{2-}{ }_{\text {ads }}+\mathrm{OH}^{-}} \\
{\left[\mathrm{WO}_{4}(\mathrm{Ni})\right]^{2-}{ }_{\text {ads }}+4 \mathrm{H}_{2} \mathrm{O}+6 \mathrm{e}^{-} \rightarrow \mathrm{W}^{0}+\mathrm{Ni}^{0}+8 \mathrm{OH}^{-}}
\end{gathered}
$$

However, in the bath containing $60 \mathrm{~g} \mathrm{~L}^{-1} \mathrm{Na}_{2} \mathrm{WO}_{4} 2 \mathrm{H}_{2} \mathrm{O}$ (the mole ratio of $\mathrm{Ni}$ and $\mathrm{W}$ in the bath is 1:4), the $W$ content in coatings were hardly unchanged by the current density. Deposition of $\mathrm{W}$ may be induced by means of the mixed complex, similarly to the ternary complex of $\left[(\mathrm{Ni})_{\mathrm{p}}\left(\mathrm{WO}_{4}\right)_{\mathrm{q}}(\mathrm{Cit})_{\mathrm{m}}\right]^{2(\mathrm{p}-\mathrm{q}-1.5 \mathrm{~m})}$ in the citrate system [7]. The ternary complex is an active species, with the lower reduction potential, so Equation (7) is the main reduction process. Therefore, the $\mathrm{W}$ content in the coatings is almost a constant:

$\left[(\mathrm{Ni})_{\mathrm{p}}\left(\mathrm{WO}_{4}\right)_{\mathrm{q}}\left(\mathrm{P}_{2} \mathrm{O}_{7}\right)_{\mathrm{m}}\right]^{2(\mathrm{p}-\mathrm{q}-2 \mathrm{~m})}+4 \mathrm{sH}_{2} \mathrm{O}+(6 \mathrm{~s}+\mathrm{p}) \mathrm{e}^{-} \rightarrow \mathrm{sW}^{0}+\mathrm{p} \mathrm{Ni}^{0}+(\mathrm{q}-\mathrm{s}) \mathrm{WO}_{4}{ }^{2-}+8 \mathrm{sOH}^{-}+\mathrm{mP}_{2} \mathrm{O}_{7}{ }^{4-}$

Figure 2 shows the SEM images of Ni-W alloy coatings prepared in the bath containing $40 \mathrm{~g} \mathrm{~L}^{-1} \mathrm{Na}_{2} \mathrm{WO}_{4} 2 \mathrm{H}_{2} \mathrm{O}$ at different current densities of $4,6,8$ and $10 \mathrm{~A} \mathrm{dm}^{-2}$; the SEM image of the Ni-W alloy coating prepared in $20 \mathrm{~g} \mathrm{~L}^{-1}$ and $60 \mathrm{~g} \mathrm{~L}^{-1} \mathrm{Na}_{2} \mathrm{WO}_{4} 2 \mathrm{H}_{2} \mathrm{O}$ bath is shown in Figure S1. It can be seen that the surface morphology of these Ni-W coatings is compact and flat without cracks. The morphology of the bright and compact Ni-W alloy coatings is mainly controlled by additives. The Ni-W alloy without additives has a honeycomb structure, as shown in Figure S2.

Figure 3 presents the $\mathrm{XRD}$ pattern of the as-deposited Ni-W alloy prepared in the bath containing $40 \mathrm{~g} \mathrm{~L}^{-1} \mathrm{Na}_{2} \mathrm{WO}_{4} 2 \mathrm{H}_{2} \mathrm{O}$ at $4,6,8$ and $10 \mathrm{~A} \mathrm{dm}^{-2}$. It can be seen that the main X-ray diffraction wide peak of the Ni-W coating appears at $2 \theta$, between 40 and $47^{\circ}$, suggesting that it has a partly amorphous structure. The remaining two weak diffraction peaks are presented at about $2 \theta=50.9$ and $75.2^{\circ}$. These three diffraction peaks can be assigned to the FCC Ni phase (JCPDS No: 04-0850). Due to the larger atomic radius of $\mathrm{W}$, the introduction of $\mathrm{W}$ results in the $2 \theta$ shift to a low angle, indicating a bigger lattice parameter. Compared with the $\mathrm{Ni}_{17} \mathrm{~W}_{3}$ alloy (JCPDS No: 65-4828), the characteristic peaks are more positive because of the lower $\mathrm{W}$ content. The XRD patterns of $20 \mathrm{~g} \mathrm{~L}^{-1}$ and $60 \mathrm{~g} \mathrm{~L}^{-1} \mathrm{Na}_{2} \mathrm{WO}_{4} 2 \mathrm{H}_{2} \mathrm{O}$ baths are shown in Figure S3. It can be seen that the coating with a low tungsten concentration has a good crystallinity, and the current density will also affect the crystallinity of the coating. 


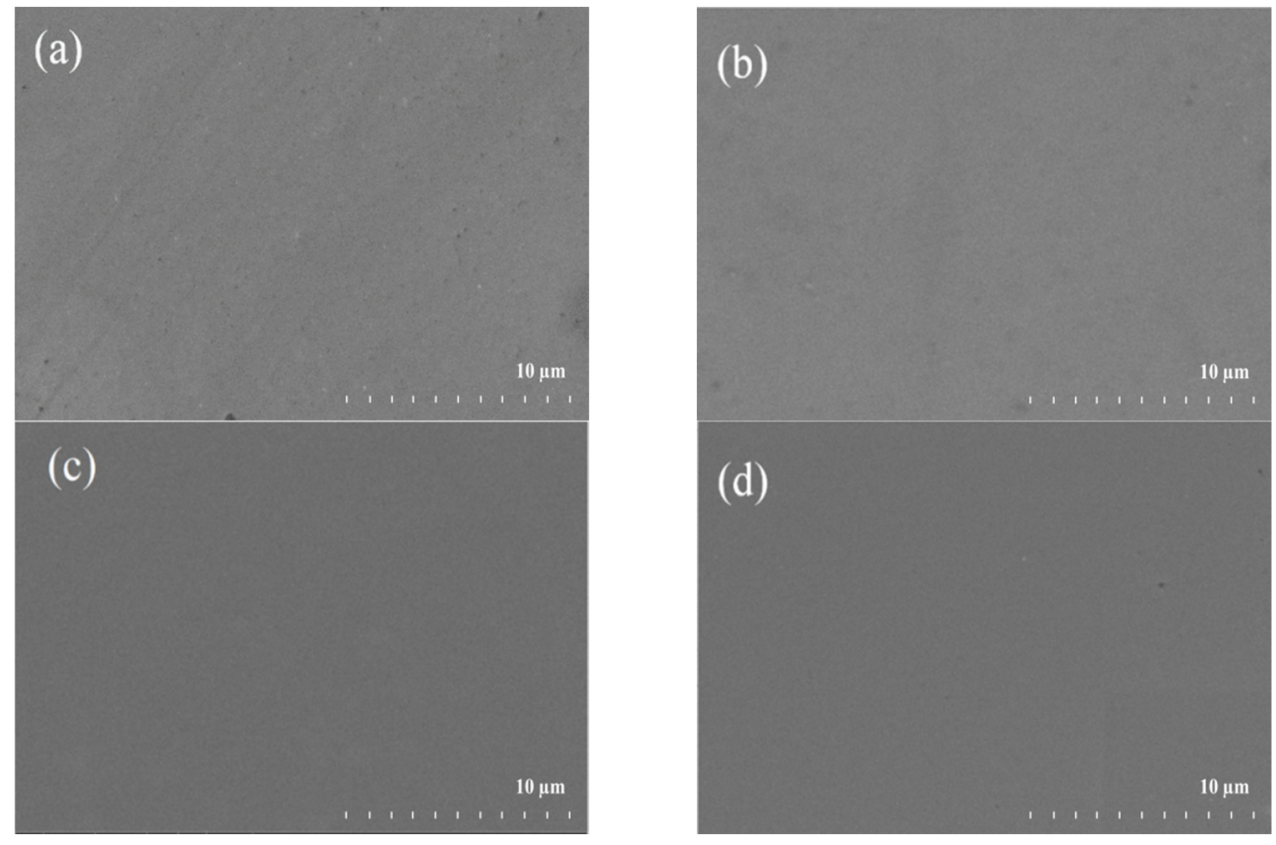

Figure 2. SEM images of Ni-W alloy coatings prepared from the pyrophosphate system at a temperature of $40{ }^{\circ} \mathrm{C}$, at different current densities of (a) 4, (b) 6, (c) 8 and (d) $10 \mathrm{~A} \mathrm{dm}^{-2}$.

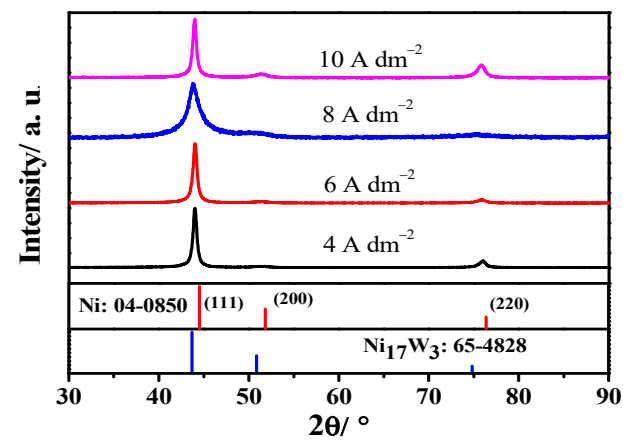

Figure 3. The XRD patterns of as-deposited alloys prepared at $4,6,8$, and $10 \mathrm{~A} \mathrm{dm}^{-2}$ current densities.

\subsection{Heat Treatment of Ni-15 wt.\% W Alloy}

After the continuous application of the Ni-W alloy electrodeposition bath was completed, a $40 \mathrm{~g} \mathrm{~L}^{-1} \mathrm{C}_{\mathrm{w}}$ bath, which controls $\mathrm{C}_{\mathrm{w}}$ more effectively in situ, was selected to prepare a Ni-15 wt.\% W alloy coating for its subsequent characterization.

The heat treatment of the Ni-15 wt.\% W alloy was carried out in the air at 200 to $700{ }^{\circ} \mathrm{C}$. Figure 4 shows its TG(Thermogravimetric analysis) and DSC(Differential Scanning Calorimetry) curves, and the insets are the photos of the Ni-15 wt.\% W alloy annealed at different temperatures for $2 \mathrm{~h}$. From the TG curve, it can be seen that, at less than $500{ }^{\circ} \mathrm{C}$, the $\mathrm{Ni}-15 \mathrm{wt} . \% \mathrm{~W}$ alloy did not become heavier, suggesting an antioxidant property of the alloy below $400{ }^{\circ} \mathrm{C}$. From the insets it can be observed that the bright surface was maintained at 200 and $300{ }^{\circ} \mathrm{C}$ and became slightly orange at $400{ }^{\circ} \mathrm{C}$, while at $500{ }^{\circ} \mathrm{C}$ its surface was oxidized to a brown color and the weight slightly increased. Although the oxidation became violent when increasing the annealed temperature, the weight increment was still less than $2.5 \%$ until $800{ }^{\circ} \mathrm{C}$. The exothermic behavior of the DSC curve for $\mathrm{Ni}-15 \mathrm{wt} . \% \mathrm{~W}$ alloy could be clearly seen, because the amorphous structure was crystallized to release heat. When over $500^{\circ} \mathrm{C}$, the heat flow increased rapidly, resulting from the surface oxidization of the alloy. 


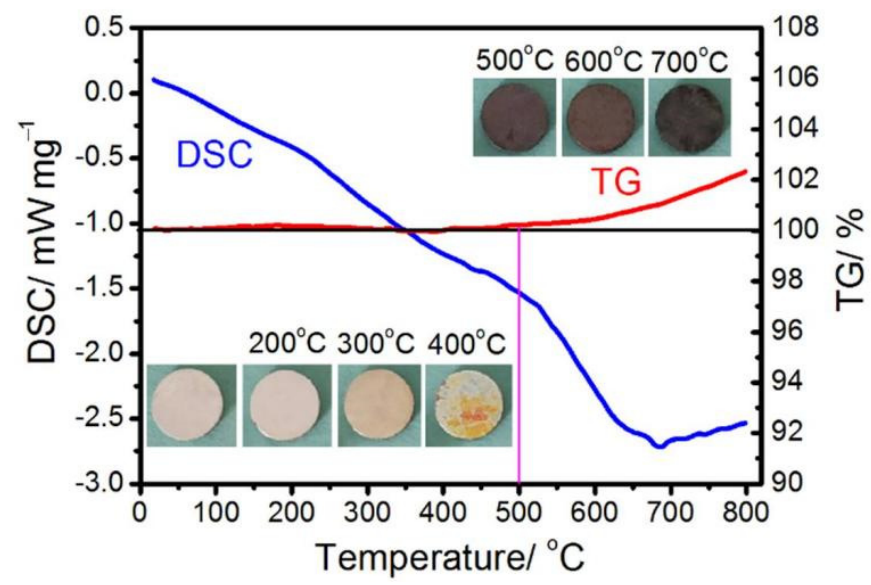

Figure 4. TG and DSC curves of theNi-15 wt.\% W alloy.

Figure 5 shows the XRD pattern evolution of the Ni-15 wt.\% W alloy along with the annealed temperature. It can be difficult to see that the (1 111 ) peak has increased when the annealed temperature is below $500{ }^{\circ} \mathrm{C}$, suggesting that a fine grain is formed during the transformation from the amorphous to the nanocrystalline structure. The (1 111 ) peak rapidly grows up at $500{ }^{\circ} \mathrm{C}$ and $600{ }^{\circ} \mathrm{C}$, forming coarse grains. At the same time, the (2 20$)$ and (2 00 ) peaks also become strong, implying that the phase is closer to the FCC Ni phase (JCPDS No: 04-0850). Although the oxidation of the Ni-15 wt.\% W alloy occurs at $500{ }^{\circ} \mathrm{C}$ and $600{ }^{\circ} \mathrm{C}$ according to the TG data, the new phase peaks do not appear, indicating that the very thin oxide layer is formed. The result is consistent with that of TG. At $700{ }^{\circ} \mathrm{C}$, the forming thick oxide layer resulting in weaker diffraction peaks, and thus new diffraction peaks appear at 30.7 and $36.3^{\circ}$, as the magnified XRD pattern shows in Figure 5. According to the Debye-Scheller formula, the grain size of the strongest peak of the (111) crystal plane was calculated, and the results are listed in Table 2. It can be observed that the increase in the annealing temperature from $200{ }^{\circ} \mathrm{C}$ to $400{ }^{\circ} \mathrm{C}$ corresponds to the slow growth in grain size from $10.23 \mathrm{~nm}$ to $12.96 \mathrm{~nm}$, and the temperature rapidly increases to $26.21 \mathrm{~nm}$ at $500{ }^{\circ} \mathrm{C}$ and $36.03 \mathrm{~nm}$ at $600{ }^{\circ} \mathrm{C}$.

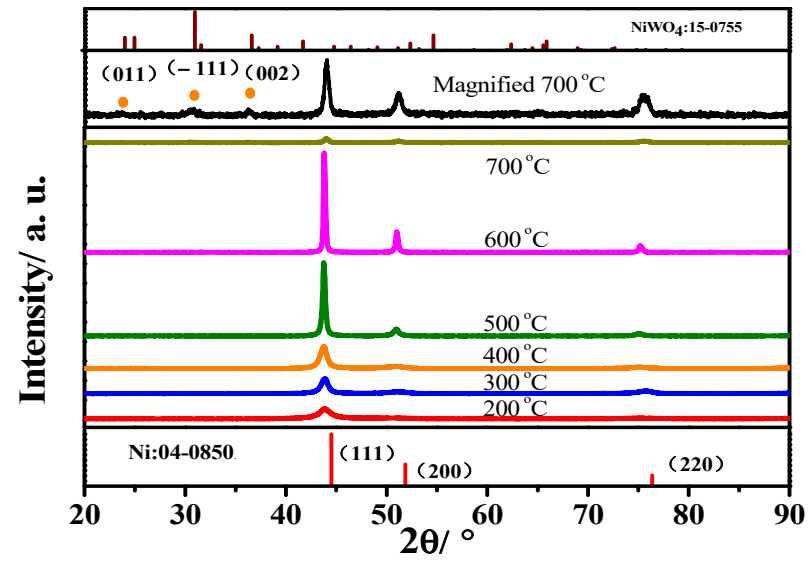

Figure 5. The XRD pattern evolution of theNi-15 wt.\% $\mathrm{W}$ alloy along with the heat treatment temperature. 
Table 2. Grain size of Ni-15 wt.\% W alloy as-deposited and annealed.

\begin{tabular}{cccc}
\hline $\mathbf{T} /{ }^{\circ} \mathbf{C}$ & $\mathbf{2 \theta} /{ }^{\circ}$ & $\beta /{ }^{\circ}$ & $\mathbf{d} / \mathbf{n m}$ \\
\hline As-deposited & 43.849 & 0.629 & 13.46 \\
200 & 43.89 & 0.828 & 10.23 \\
300 & 43.849 & 0.689 & 12.29 \\
400 & 43.747 & 0.653 & 12.96 \\
500 & 43.748 & 0.323 & 26.21 \\
600 & 43.789 & 0.235 & 36.03 \\
700 & 44.034 & 0.451 & - \\
\hline
\end{tabular}

\subsection{Microhardness of Ni-15 wt.\% W Alloy}

Below $500{ }^{\circ} \mathrm{C}$, the Ni-15 wt.\% W alloy surface is compact, flat and without cracks, so the microhardness is directly measured. The optical indentation images of the Ni-15 wt. $\% \mathrm{~W}$ alloy as-deposited and annealed at 300 and $400{ }^{\circ} \mathrm{C}$ are shown in Figure 6a-c, respectively. Although there is a slight oxidation at $400{ }^{\circ} \mathrm{C}$, the diamond indentation shapes are clearly observed. It is found that the Ni-15 wt.\% W alloy does not crack under the pressure of the diamond indenter, suggesting a good ductility. As shown in Figure $6 \mathrm{~d}$, the microhardness value of the sample was displayed. The microhardness of Ni-15 wt.\% W as-deposited alloy coating at $534 \mathrm{HV}$ was similar to the reported value of 460-740 HV [24]. When the annealed temperature was increased from $200^{\circ} \mathrm{C}$ to $300{ }^{\circ} \mathrm{C}$, the microhardness increased slowly and then rapidly reached the maximum of $895 \mathrm{HV}$ at $400{ }^{\circ} \mathrm{C}$. In contrast, the higher published value of $\mathrm{Ni}-21$ at. $\% \mathrm{~W}$ was $1005 \mathrm{HV}$ [25], but this was still higher than the value of 650-800 HV studied by Haj-Taieb et al. [26]. This difference is mainly caused by the difference in $\mathrm{W}$ content. Because the growth of the Ni-W crystal phase promotes grain refinement and is strengthened according to the DSC and XRD data, it promotes the increase in microhardness, as evidenced by the results of many reports $[7,18,27]$. When the annealed temperature is higher than $400{ }^{\circ} \mathrm{C}$, the microhardness slightly decreases because of the coarse crystals.
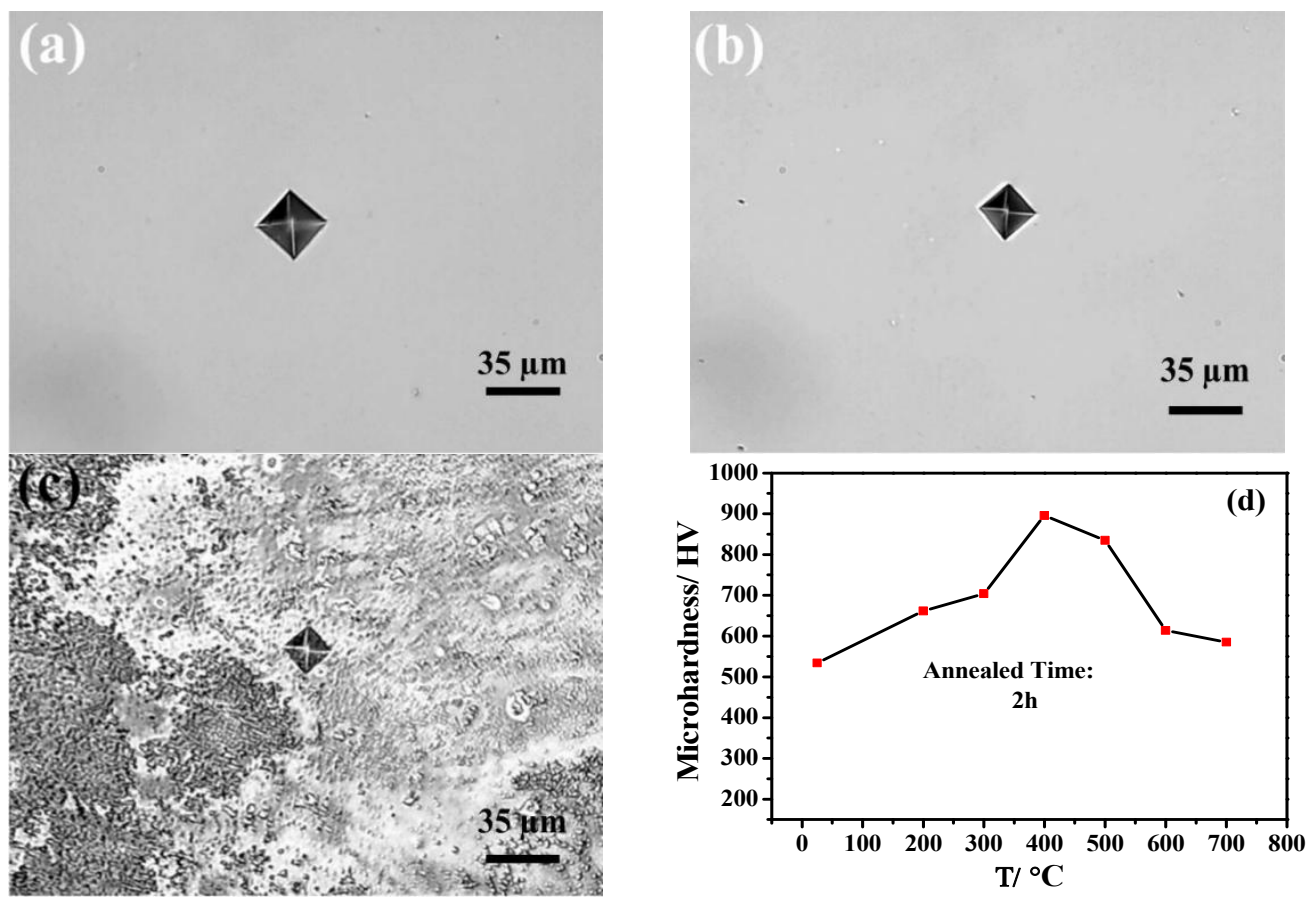

Figure 6. Indentation optical images of Ni-15 wt.\% W alloy coating (a) as-deposited, (b) annealed at $300{ }^{\circ} \mathrm{C}$ and (c) annealed at $400{ }^{\circ} \mathrm{C}$. (d) The microhardness curve annealed at different temperatures of from 200 to $700{ }^{\circ} \mathrm{C}$ in air for $2 \mathrm{~h}$. 


\subsection{Electrochemical Properties of Ni-15 wt.\% W Alloy Coating}

The corrosion resistance of Ni-15 wt.\% W alloy coating was estimated by Tafel curves and EIS spectra measured in the $3.5 \mathrm{wt} . \% \mathrm{NaCl}$ solution, adding a base material of Q235 carbon steel disks $(\mathrm{Fe})$ as a test for comparison. As Figure 7 and Figure S4 show, the corrosion potential $\left(\mathrm{E}_{\mathrm{corr}}\right.$ ) was clearly and positively shifted after the Ni-15 wt. $\% \mathrm{~W}$ alloy was electrodeposited on the Q235 carbon steel disks, implying an improved corrosion resistance [28]. Along with the increase in the annealed temperature, the positive potential increment $(\Delta \mathrm{E})$ also increased. At $600{ }^{\circ} \mathrm{C}, \Delta \mathrm{E}$ dramatically improved because of the surface oxidization. The corrosion potential and current $\left(\mathrm{I}_{\text {corr }}\right)$ were analyzed by the Tafel extrapolation method, and the results are shown in Table 3 and Table S1. $\mathrm{I}_{\text {corr }}$ decreased with the annealed temperature, indicating a corrosion resistance improvement. This was attributed to the passivation of the Ni-W coating $[29,30]$.

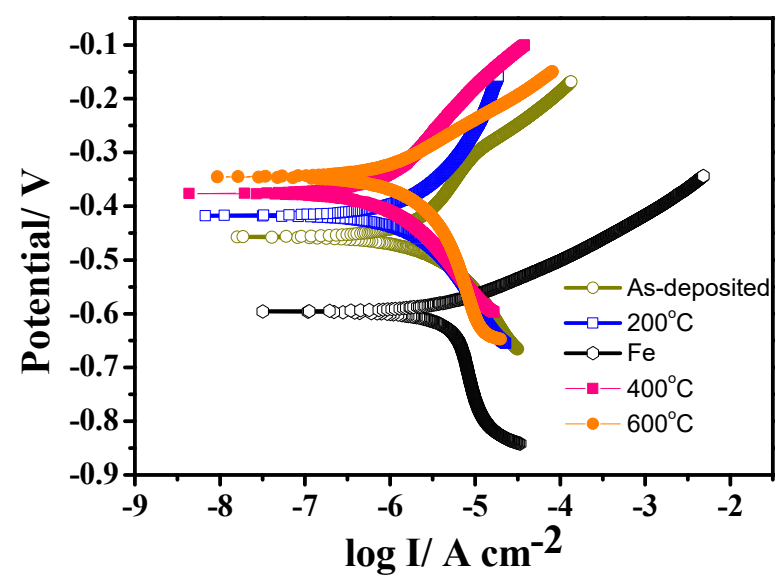

Figure 7. Tafel curves of Ni-15 wt. $\% \mathrm{~W}$ coatings as-deposited and annealed at different temperatures in air for $2 \mathrm{~h}$.

Table 3. Corrosion resistance of Ni-15 wt. $\% \mathrm{~W}$ alloy coatings as-deposited and annealed.

\begin{tabular}{ccccc}
\hline Sample & $\mathbf{T} /{ }^{\circ} \mathbf{C}$ & $\mathbf{I}_{\text {corr }} / \boldsymbol{\mu A . c m} \mathbf{A m}^{-2}$ & $\mathbf{E}_{\text {corr }}$ (vs. SCE)/mV & $\Delta \mathbf{E}_{\text {corr }} / \mathbf{m V}$ \\
\hline Fe & - & 5.71 & -611 & 0 \\
\hline \multirow{2}{*}{ Ni-W alloy } & As-deposited & 4.45 & -447 & 164 \\
coating & 200 & 2.33 & -440 & 171 \\
& 400 & 2.02 & -386 & 225 \\
& 600 & 1.91 & -349 & 262 \\
\hline
\end{tabular}

Figure 8a and Figure S5 show the EIS spectra of the Ni-15 wt.\% W alloy coatings. All Nyquist curves present a flat semicircle which indicates that the $\mathrm{Fe}$, as-deposited and annealed Ni-W alloy coatings have undergone the same corrosion reaction process. The different semicircle sizes indicate that the difficulty and speed of the corrosion reaction are different [31]. Fitting through the equivalent circuit diagram of Figure 8b, the results are shown in Table 4 and Table S2: where $R_{c t}$ is the charge transfer resistance, $R_{S}$ is the solution resistance, $\mathrm{CPE}_{1}$ is the electric double layer capacitor, $\mathrm{CPE}_{2}$ is the coating capacitor and $R_{f}$ is the coating resistance [32]. It can be seen that the $R_{c t}$ is largely improved from about 1000 to over 20,000 $\Omega \mathrm{cm}^{2}$, after coating the Ni-W alloy in the Fe substrate, indicating that the coatings improved corrosion resistance [33]. Moreover, this value was much higher than the reported value $\left(5619 \Omega \mathrm{cm}^{2}\right)$, and so the corrosion resistance was better than the value reported in [29]. At $600^{\circ} \mathrm{C}$, the brown oxide layer further increased the Rct, implying a better corrosion resistance. 

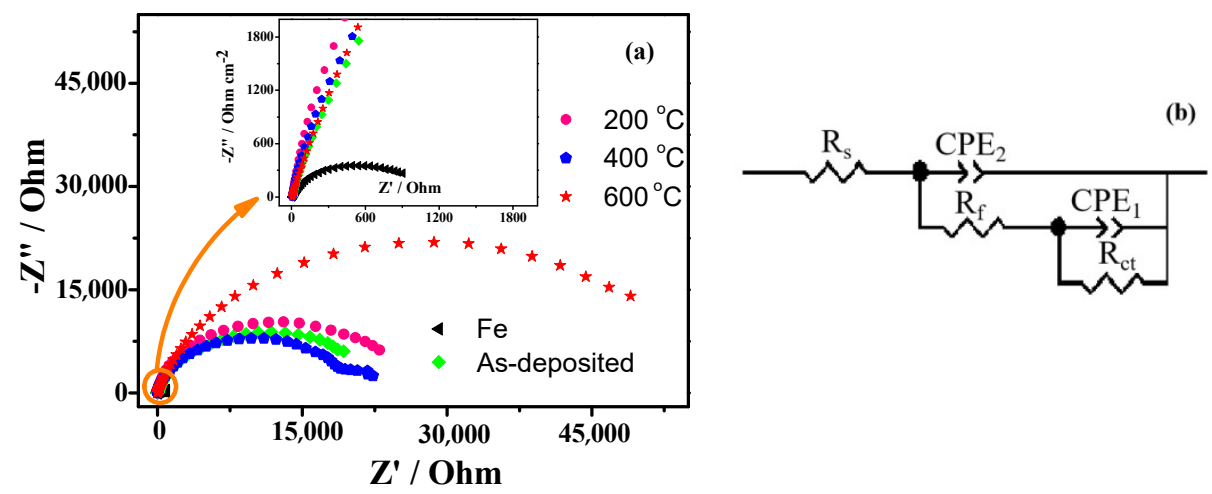

Figure 8. (a) Nyquist plots of as-deposited and annealed Ni-15 wt.\% W coated on Fe substrates. (b) Equivalent circuit diagram.

Table 4. EIS spectrum fitting results of Ni-W coating in $3.5 \mathrm{wt} . \% \mathrm{NaCl}$ solution.

\begin{tabular}{|c|c|c|c|c|c|c|c|c|}
\hline Sample & $\mathrm{T} /\left({ }^{\circ} \mathrm{C}\right)$ & $\begin{array}{c}R_{\mathrm{s}} / \\
\Omega \mathrm{cm}^{2}\end{array}$ & $\begin{array}{l}\mathrm{CPE}_{1}-\mathrm{T} / \\
\mathrm{F} \mathrm{cm}^{-2}\end{array}$ & $\mathrm{CPE}_{\mathbf{1}}-\mathrm{P}$ & $\begin{array}{c}R_{\mathrm{f}} / \\
\Omega \mathrm{cm}^{2}\end{array}$ & $\begin{array}{l}\mathrm{CPE}_{2}-\mathrm{T} / \\
\mathrm{F} \mathrm{cm}^{-2}\end{array}$ & $\mathrm{CPE}_{2}-\mathrm{P}$ & $\begin{array}{c}R_{\mathrm{ct}} / \\
\Omega \mathrm{cm}^{2}\end{array}$ \\
\hline $\mathrm{Fe}$ & - & 5.42 & 0.00059 & 0.76 & 27.61 & 0.0022 & 0.90 & 958 \\
\hline \multirow{4}{*}{$\begin{array}{l}\text { Ni-W alloy } \\
\text { coating }\end{array}$} & - & 5.39 & 0.000039 & 0.84 & 12.25 & 0.0000050 & 1.09 & 21,468 \\
\hline & 200 & 5.74 & 0.000033 & 0.85 & 5.17 & 0.0000086 & 1.05 & 22,547 \\
\hline & 400 & 5.79 & 0.000026 & 0.86 & 12.91 & 0.0000018 & 1.10 & 20,561 \\
\hline & 600 & 5.87 & 0.000044 & 0.86 & 20.62 & 0.0000015 & 1.16 & 37,552 \\
\hline
\end{tabular}

The electrocatalytic HER performance of the Ni-15 wt.\% W alloy coating was assessed in $6 \mathrm{wt}$ \% $\mathrm{NaOH}$ solution by LSV electrochemical technology. The results are shown in Figure 9 . As Figure 9 shows, the Ni-15 wt.\% W alloy coating prepared by the pyrophosphate system exhibits a good catalytic activity. It requires an overpotential of $0.55 \mathrm{~V}$ to drive a current density of $100 \mathrm{~mA} \mathrm{~cm}^{-2}$, which is lower than that of Fe (0.59 V) and much higher than that of $\mathrm{Pt}(0.17 \mathrm{~V})$. The HER activity of the compact and flat Ni-15 wt.\% W alloy coating was slightly better than that of the surface of the relatively flat Ni-W alloys [34-37] (see Table 5); as it is affected by the roughness [38], it is weaker than the nanostructured and porous Ni-W alloys [22]. The alloys' HER activity can be further improved along with the annealed temperature, suggesting that the crystallization material is better than that of the amorphous structure. This is due to the elimination of the internal stress and an increased grain growth, which positively influence the hydrogen absorption capacity of $\mathrm{Ni}-\mathrm{W}$ coating. However, at $600^{\circ} \mathrm{C}$, the HER activity becomes weaker, which is attributed to the surface oxidation state.

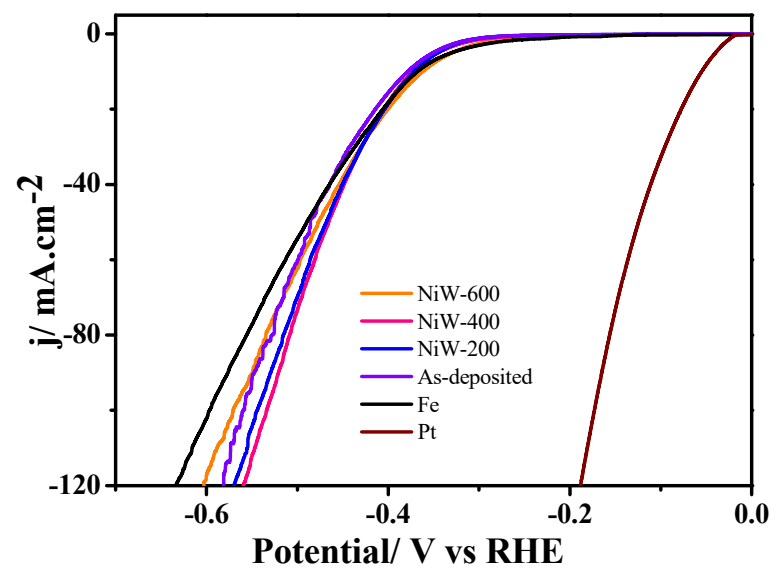

Figure 9. HER of Ni-15 wt.\% W alloy in $6 \mathrm{wt} . \% \mathrm{NaOH}$ solution as-deposited and annealed at different temperatures. For comparison, the HER curves of Fe and Pt electrodes are shown. 
Table 5. Comparison of HER over-potential of Ni-W alloys at $20 \mathrm{~mA} \mathrm{~cm}{ }^{-2}\left(\eta_{20}\right)$ and $100 \mathrm{~mA} \mathrm{~cm}^{-2}$ $\left(\eta_{100}\right)$.

\begin{tabular}{ccccc}
\hline NO. & $\eta_{\mathbf{2 0}} / \mathbf{V}$ & $\eta_{\mathbf{1 0 0}} / \mathbf{V}$ & Microstructure & Reference \\
\hline 1 & 0.41 & 0.55 & $\begin{array}{c}\text { Compact, flat } \\
\text { and without } \\
\text { cracks. }\end{array}$ & This work \\
2 & 0.56 & 0.73 & $\begin{array}{l}\text { Micro-cracks } \\
\text { Micro-cracks }\end{array}$ & {$[34]$} \\
4 & 0.47 & 0.56 & Smooth, flat, & {$[35]$} \\
5 & 0.47 & 0.54 & micro-cracks & Nodular \\
\hline
\end{tabular}

\section{Conclusions}

In summary, the compact and flat $\mathrm{Ni}-15 \mathrm{wt} . \% \mathrm{~W}$ alloy without cracks was electrodeposited from a pyrophosphate system at $40{ }^{\circ} \mathrm{C}$ and presented a high microhardness, excellent oxidation resistance, excellent corrosion resistance and good HER activity. The $\mathrm{Ni}-15 \mathrm{wt} . \% \mathrm{~W}$ coating had a microhardness of $534 \mathrm{HV}$ at room temperature and $895 \mathrm{HV}$ at $400{ }^{\circ} \mathrm{C}$, attributed to the nanocrystalline structure transformed from its as-deposited amorphous structure. Compared with the bare Fe substrate, the as-deposited and annealed $\mathrm{Ni}-15 \mathrm{wt} . \% \mathrm{~W}$ coatings possessed an improved corrosion resistance, for example, at $600{ }^{\circ} \mathrm{C}$, the coating positively shifted to $-349 \mathrm{mV}$ and $\Delta \mathrm{E}_{\text {corr }}$ is $262 \mathrm{mV}$. The low $\mathrm{I}_{\text {corr }}$ of $1.91 \mu \mathrm{A}$ $\mathrm{cm}^{-2}$ and high $R_{\mathrm{ct}}$ of $37,552 \Omega \mathrm{cm}^{2}$ for the sampled annealed at $600{ }^{\circ} \mathrm{C}$ implied an excellent corrosion resistance, attributed to the surface oxidation in the air in a high temperature environment, while the best HER activity appeared at an intermediate temperature of $400{ }^{\circ} \mathrm{C}$, attributed to the joint effect of the nanocrystalline structure formation and surface oxidation.

Supplementary Materials: The following are available online at https:/ /www.mdpi.com/article/ 10.3390/coatings11101262/s1, Figure S1: SEM images of Ni-W alloy coatings prepared from the pyrophosphate system at a temperature of $40^{\circ} \mathrm{C}$, at different current densities of (a) 4, (b) 6, (c) 8 and (d) $10 \mathrm{~A} \mathrm{dm}^{-2}$ in $20 \mathrm{~g} \mathrm{~L}^{-1} \mathrm{Na}_{2} \mathrm{WO}_{4} 2 \mathrm{H}_{2} \mathrm{O}$ bath, and at different current densities of (e) 4, (f) 6, (g) 8, and (h) $10 \mathrm{~A} \mathrm{dm}^{-2}$ in $60 \mathrm{~g} \mathrm{~L}^{-1} \mathrm{Na}_{2} \mathrm{WO}_{4} 2 \mathrm{H}_{2} \mathrm{O}$ bath, Figure S2: SEM images of nickel-tungsten alloy obtained in an additive-free bath, Figure $\mathrm{S} 3$ : $\mathrm{XRD}$ patterns of as-deposited alloys prepared at current densities of 4, 6, 8 and $10 \mathrm{~A} \mathrm{dm}^{-2}$ in dif-ferent bath concentrations (a) $20 \mathrm{~g} \mathrm{~L}^{-1} \mathrm{Na}_{2} \mathrm{WO}_{4} 2 \mathrm{H}_{2} \mathrm{O}$ and (b) $60 \mathrm{~g} \mathrm{~L}^{-1} \mathrm{Na}_{2} \mathrm{WO}_{4} 2 \mathrm{H}_{2} \mathrm{O}$, Figure S4: Tafel curves of Ni-15 wt.\% $\mathrm{W}$ coatings as-deposited and annealed at different temperatures in air for $2 \mathrm{~h}$, Figure S5: Nyquist plots of annealed Ni-15 wt.\% W coated on Fe substrates, Table S1: Corrosion resistance of Ni-15 wt.\% W alloy coatings as-deposited and annealed, Table S2: EIS spectrum fitting results of $\mathrm{Ni}-\mathrm{W}$ coating in $3.5 \mathrm{wt} . \% \mathrm{NaCl}$ solution.

Author Contributions: Conceptualization, C.S. and W.B.; Data curation, Z.S., C.S. and L.Z.; Formal analysis, F.W. and C.S.; Investigation, Z.S.; Resources, C.S. and W.B.; Validation, Y.L.; Writingoriginal draft, Z.S. and C.S.; Writing-review \& editing, Z.S. and C.S. All authors have read and agreed to the published version of the manuscript.

Funding: This research was funded by Provincial Natural Science Foundations of Hunan (2021JJ30184, 2021JJ30180, 2020JJ4243), the Scientific Research Fund of Hunan Provincial Education Department (20A108), the National Natural Science Foundation of China (51561032) and Doctoral Research Fund of Hunan Institute of Engineering (09001003-21017).

Acknowledgments: The authors acknowledge the financial support from Provincial Natural Science Foundations of Hunan (2021JJ30184, 2021JJ30180, 2020JJ4243), the Scientific Research Fund of Hunan Provincial Education Department (20A108), the National Natural Science Foundation of China (51561032) and Doctoral Research Fund of Hunan Institute of Engineering (09001003-21017).

Conflicts of Interest: The authors declare no conflict of interest. 


\section{References}

1. Wang, Y.; Zhou, Q.; Li, K.; Zhong, Q.; Bui, Q.B. Preparation of Ni-W-SiO 2 nanocomposite coating and valuation of its hardness and corrosion resistance. Ceram. Int. 2015, 41, 79-84. [CrossRef]

2. Määttä, A.; Kanerva, U.; Vuoristo, P. Structure and Tribological Characteristics of HVOF Coatings Sprayed from Powder Blends of $\mathrm{Cr}_{3} \mathrm{C}_{2}-25 \mathrm{NiCr}$ and NiCrBSi Alloy. J. Therm. Spray Technol. 2010, 20, 366-371. [CrossRef]

3. Huang, B.; Gao, Y.; Chen, P.; Xiong, W.; Tang, J. Microstructure and properties of Ni $+\mathrm{B}_{4} \mathrm{C} / \mathrm{Ti}$ coatings by high-frequency induction cladding. Surf. Innov. 2019, 7, 59-67. [CrossRef]

4. Zikin, A.; Antonov, M.; Hussainova, I.; Katona, L.; Gavrilović, A. High temperature wear of cermet particle reinforced NiCrBSi hardfacings. Tribol. Int. 2013, 68, 45-55. [CrossRef]

5. Garrido, A.H.; González, R.; Cadenas, M.; Battez, A.H. Tribological behavior of laser-textured NiCrBSi coatings. Wear 2011, 271, 925-933. [CrossRef]

6. Gyftou, P.; Stroumbouli, M.; Pavlatou, E.A.; Asimidis, P.; Spyrellis, N. Tribological study of Ni matrix composite coatings containing nano and micro SiC particles. Electrochim. Acta 2005, 50, 4544-4550. [CrossRef]

7. Allahyarzadeh, M.H.; Aliofkhazraei, M.; Rezvanian, A.R.; Torabinejad, V.; Sabour Rouhaghdam, A.R. Ni-W electrodeposited coatings: Characterization, properties and applications. Surf. Coat. Technol. 2016, 307, 978-1010. [CrossRef]

8. Hosseini, M.G.; Abdolmaleki, M.; Sadjadi, S.A.S. Electrodeposition and mechanical properties of Ni-W-B composites from tartrate bath. Prot. Met. Phys. Chem. Surf. 2010, 46, 117-122. [CrossRef]

9. Kirihara, S.; Umeda, Y.; Tashiro, K.; Honma, H.; Takai, O. Development of Ni-W alloy plating as a substitution of hard chromium plating. Trans. Mater. Res. Soc. Jpn. 2016, 41, 35-39. [CrossRef]

10. Donten, M.; Cesiulis, H.; Stojek, Z. Electrodeposition and properties of Ni-W, Fe-W and Fe-Ni-W amorphous alloys. A comparative study. Electrochim. Acta 2000, 45, 3389-3396. [CrossRef]

11. Fang, M.; Dong, G.; Wei, R.; Ho, J.C. Hierarchical Nanostructures: Hierarchical Nanostructures: Design for Sustainable Water Splitting. Adv. Energy Mater. 2017, 7, 1770135. [CrossRef]

12. Zhang, W.; Qi, J.; Liu, K.; Cao, R. A Nickel-Based Integrated Electrode from an Autologous Growth Strategy for Highly Efficient Water Oxidation. Adv. Energy Mater. 2016, 6, 1502489. [CrossRef]

13. Pletcher, D.; Li, X. Prospects for alkaline zero gap water electrolysers for hydrogen production. Int. J. Hydrogen Energy 2011, 36, 15089-15104. [CrossRef]

14. Du, Y.; Li, Z.; Liu, Y.; Yang, Y.; Wang, L. Nickel-iron phosphides nanorods derived from bimetallic-organic frameworks for hydrogen evolution reaction. Appl. Surf. Sci. 2018, 457, 1081-1086. [CrossRef]

15. Zheng, Y.; Jiao, Y.; Zhu, Y.; Li, L.H.; Han, Y.; Chen, Y.; Du, A.; Jaroniec, M.; Qiao, S.Z. Hydrogen evolution by a metal-free electrocatalyst. Nat. Commun. 2014, 5, 15729-15735. [CrossRef]

16. McKone, J.R.; Marinescu, S.C.; Brunschwig, B.S.; Winkler, J.R.; Gray, H.B. Earth-abundant hydrogen evolution electrocatalysts. Chem. Sci. 2014, 5, 865-878. [CrossRef]

17. Karaguiozova, Z.; Stavrev, S.; Babul, T.; Ciski, A. Influence of cubic nanostructure additions on the properties of electroless coatings. Int. J. Nanomanufacturing 2010, 5, 129-138. [CrossRef]

18. Wang, H.-T.; Sheu, H.-H.; Ger, M.-D.; Hou, K.-H. The effect of heat treatment on the microstructure and mechanical properties of electrodeposited nanocrystalline Ni-W/diamond composite coatings. Surf. Coat. Technol. 2014, 259, 268-273. [CrossRef]

19. Yamasaki, T.; Oda, N.; Matsuoka, H.; Fukami, T. Tensile strength of electrodeposited nanocrystalline Ni-W alloys with finely dispersed micrometer-sized array through-holes. Mater. Sci. Eng. A 2007, 449-451, 833-835. [CrossRef]

20. Suvorov, D.; Gololobov, G.; Tarabrin, D.; Slivkin, E.; Karabanov, S.; Tolstoguzov, A. Electrochemical Deposition of Ni-W Crack-Free Coatings. Coatings 2018, 8, 233. [CrossRef]

21. Ghorbanian, B.; Tajally, M.; Khoie, S.M.M.; Tavakoli, H. Corrosion Behavior of MoS2-Incorporated PEO Coatings Prepared on Al Alloy. Surf. Innov. 2020, 8, 252-262. [CrossRef]

22. Jameei Rad, P.; Aliofkhazraei, M.; Barati Darband, G. Ni-W nanostructure well-marked by Ni selective etching for enhanced hydrogen evolution reaction. Int. J. Hydrogen Energy 2019, 44, 880-894. [CrossRef]

23. Krasikov, A.V.; Krasikov, V.L. Mechanism of Nickel-Tungsten Alloy Electrodeposition from Pyrophosphate Electrolyte. Bull. SPbSTI 2016, 36, 12-23. [CrossRef]

24. Panagopoulos, C.N.; Plainakis, G.D.; Lagaris, D.A. Nanocrystalline Ni-W coatings on copper. Mater. Sci. Eng B 2011, 176, 477-479. [CrossRef]

25. Yin, D.; Marvel, C.J.; Cui, F.Y.; Vinci, R.P.; Harmer, M.P. Microstructure and fracture toughness of electrodeposited Ni-21 at.\% W alloy thick films. Acta Mater. 2018, 143, 272-280. [CrossRef]

26. Haj-Taieb, M.; Haseeb, A.S.M.A.; Caulfield, J.; Bade, K.; Aktaa, J.; Hemker, K.J. Thermal stability of electrodeposited LIGA Ni-W alloys for high temperature MEMS applications. Microsyst. Technol. 2008, 14, 1531-1536. [CrossRef]

27. Hwang, W.S.; Lee, J.J. Effects of Heat Treatment on Hardness of Nanocrystalline Ni-W Electrodeposits. Mater. Sci. Forum 2006, 510-511, 1126-1129. [CrossRef]

28. Hernn, D.M.V.; Aida, M.E.; Gilberto, B.G. Detailed Study of the Electrochemical Behavior of Low Reflectivity TiAlN Coatings. Surf. Innov. 2021, 9, 293-307. [CrossRef]

29. Hosseini, M.G.; Abdolmaleki, M.; Ghahremani, J. Investigation of corrosion resistance of electrodeposited Ni-W/SiC composite coatings. Corros. Eng. Sci. Technol. 2013, 49, 247-253. [CrossRef] 
30. Popczyk, M.; Kubisztal, J.; Swinarew, A.S.; Waśkiewicz, Z.; Stanula, A.; Knechtle, B. Corrosion Resistance of Heat-Treated Ni-W Alloy Coatings. Materials 2020, 13, 1172. [CrossRef]

31. Xiao, Y.; Yu, L.B.; Zhong, Q.J.; Gu, J.F.; Zhou, Q.Y.; Zhong, Q.D. The Effect of Cl- Concentration on the Corrosion Behavior of Electroplated Cu-Ni-W Alloy Coating. Adv. Mater. Res. 2013, 785-786, 953-956. [CrossRef]

32. Jinlong, L.; Zhuqing, W.; Tongxiang, L.; Suzuki, K.; Hideo, M. Effect of tungsten on microstructures of annealed electrodeposited Ni-W alloy and its corrosion resistance. Surf. Coat. Technol. 2018, 337, 516-524. [CrossRef]

33. Gao, Y.; Wu, Y.; He, H.; Tan, W. Potentiostatic electrodeposition of Ni-Se-Cu on nickel foam as an electrocatalyst for hydrogen evolution reaction. J. Colloid Interface Sci. 2020, 578, 555-564. [CrossRef] [PubMed]

34. Elias, L.; Scott, K.; Hegde, A.C. Electrolytic Synthesis and Characterization of Electrocatalytic Ni-W Alloy. J. Mater. Eng. Perform. 2015, 24, 4182-4191. [CrossRef]

35. Elias, L.; Cao, P.; Hegde, A.C. Magnetoelectrodeposition of Ni-W alloy coatings for enhanced hydrogen evolution reaction. RSC Adv. 2016, 6, 111358-111365. [CrossRef]

36. Elias, L.; Hegde, A.C. Electrolytic Synthesis of Ni-W-MWCNT Composite Coating for Alkaline Hydrogen Evolution Reaction. J. Mater. Eng. Perform. 2018, 27, 1033-1039. [CrossRef]

37. Ábel, M.; Záchenská, J.; Dobročka, E.; Zemanová, M. Electrocatalytic properties of pulse plated Ni-W alloy coatings in alkaline electrolytes. Trans. IMF 2021, 99, 23-28. [CrossRef]

38. Ahn, S.H.; Choi, I.; Park, H.Y.; Hwang, S.J.; Yoo, S.J.; Cho, E.; Kim, H.J.; Henkensmeier, D.; Nam, S.W.; Kim, S.K.; et al. Effect of morphology of electrodeposited Ni catalysts on the behavior of bubbles generated during the oxygen evolution reaction in alkaline water electrolysis. Chem. Commun. 2013, 49, 9323-9325. [CrossRef] 